\title{
Carbon and Oxygen Isotopic Stratigraphy of Mesoproterozoic Carbonate Sequences (1.6-1.4 Ga) from Yanshan in North China
}

\author{
Kuang Hongwei, ${ }^{1,2}$ Liu Yongqing, ${ }^{1}$ Li Jiahua, ${ }^{3}$ Peng Nan, ${ }^{3}$ Luo Shunshe, ${ }^{3}$ and Cen Chao ${ }^{2}$ \\ ${ }^{1}$ Institute of Geology, Chinese Academy of Geological Sciences, Beijing 100037, China \\ ${ }^{2}$ Key Laboratory of Exploration Technologies for Oil and Gas Resources, School of Geophysics and Oil Resources, \\ Yangtze University, Ministry of Education of China, Jingzhou 434023, China \\ ${ }^{3}$ Insitute of Geosciences, Yangtze University, Jingzhou 434023, China \\ Correspondence should be addressed to Kuang Hongwei, kuanghw@126.com
}

Received 13 October 2010; Revised 22 December 2010; Accepted 17 January 2011

Academic Editor: Henk Brinkhuis

Copyright ( $) 2011$ Kuang Hongwei et al. This is an open access article distributed under the Creative Commons Attribution License, which permits unrestricted use, distribution, and reproduction in any medium, provided the original work is properly cited.

In Yanshan, located in the northern part of North China, Mesoproterozoic carbonate sequences $(1.6-1.4 \mathrm{Ga})$ form a $10,000 \mathrm{~m}$ thick succession in an aulacogen basin. Carbon and oxygen isotope $\left(\delta^{13} \mathrm{O}\right.$ and $\delta^{18} \mathrm{O}$, resp.) data were obtained from 110 carbonate samples across three sections of these Mesoproterozoic deposits. From the early to late Mesoproterozoic, low negative values of $\delta^{13} \mathrm{O}$ appear, followed by low positive variation and then a stable increase. An abrupt decrease in $\delta^{13} \mathrm{O}$ values, with subsequent rapid increase, is found at the end of the Mesoproterozoic. During the whole Mesoproterozoic, $\delta^{18} \mathrm{O}$ shows a mainly negative trend and occasional highly negative isotopic shifts (from lower to upper deposits). Whole-rock carbon and oxygen isotopic compositions and profiles must be studied to provide a paleogeochemical record that can be associated with paleocean sedimentary environments, temperature, biological productivity, and sea-level fluctuations. Results of the present study correlate well with other international carbon and oxygen isotope profiles, suggesting that a global marine geochemical system existed during the interval of 1.6-1.4 Ga under a globally united tectonic, sedimentary, and geochemical background.

\section{Introduction}

Yanshan, located in the northern part of North China, has a well-developed Mesoproterozoic marine strata-type section, that is nearly $10,000 \mathrm{~m}$ thick (Figure 1 ). These strata record information on the paleogeography, paleoenvironment, and paleocean geochemistry, providing clues to life and sedimentary evolution at the North China Craton during the Late Precambrian [1]. The Mesoproterozoic stratigraphy of Yanshan displays good depositional succession, very little deformation and alteration of metamorphism, and is widely known nationally and internationally.

Since establishment of the strata type in Yanshan in the 1930s [2], numerous studies have examined the stratigraphy, sedimentology, paleontology, geochronology, and geochemistry [3] and reported on carbon and oxygen isotopes [4-12]. Zhong and Chen [4] examined the isotopic composition of the Gaoyuzhuang Formation and the Yangzhuang Formation based on oxygen and carbon isotopic data (152 values) collected from the Gaoyuzhuang to Yangzhuang Formations at the Ming Tombs, Beijing and in Jixian, Tianjin. Wang and Chen [5] studied oxygen-carbon isotopic changes of the Tieling Formation using isotopic data (94 values). Zhao [6] obtained 17 samples mainly from Mesoproterozoic carbonates in Jixian, Tianjin. Zhao et al. [7] analyzed 29 samples from Mesoproterozoic carbonates at the Ming Tombs, Beijing, while Xiao et al. [8] reported oxygen and carbon isotope findings from Mesoproterozoic carbonates from Jixian, Tianjin. Li et al. [9] studied the oxygen and carbon isotopic composition and characteristics of the Wumishan Formation at the Ming Tombs, Beijing. Li et al. [11] and Chu et al. [12] also studied the oxygen and carbon isotopic compositions, respectively, of Mesoneoproterozoic samples from Jixian, Tianjin.

Previous studies have focused mainly on Mesoproterozoic samples from the Ming Tombs in Beijing and Jixian, 


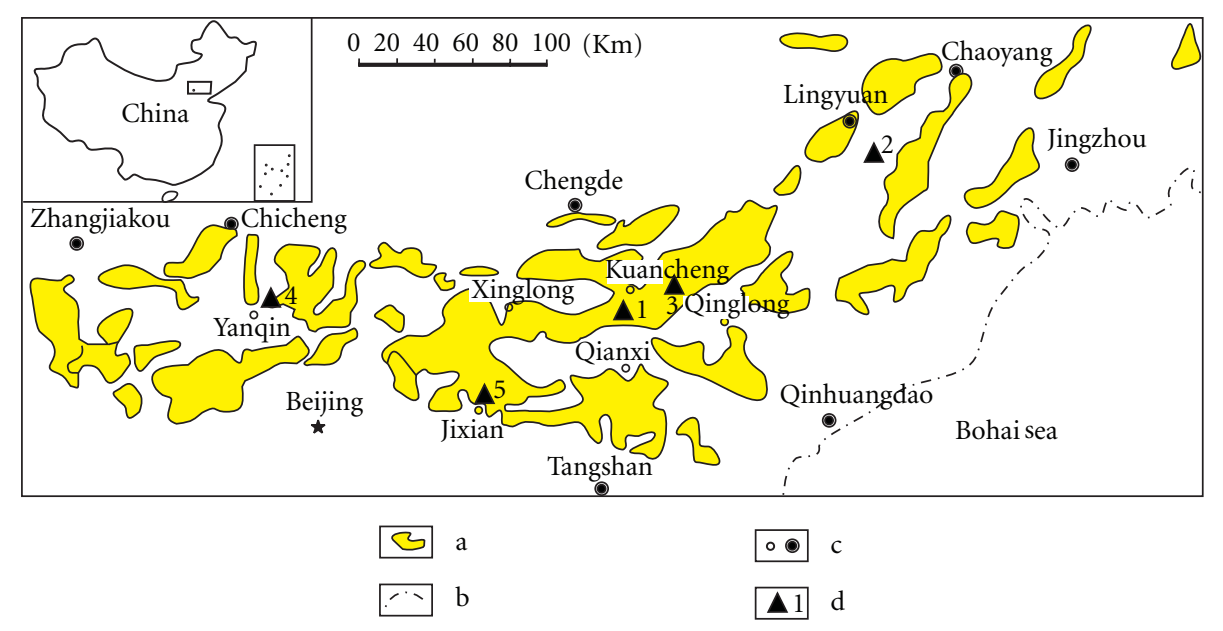

Figure 1: Locations of sections and stratigraphic distribution of Mesoproterozoic in Yanshan, North China (modified after Zhu et al. [13]). (1) Gaoyuzhuang Formation and Yangzhuang Formation section in Jianshanzi, Kuancheng, Northern Hebei; (2) Wumishan Formation section in Weizhangzi, Lingyuan, Western Liaoning; (3) Hongshuizhuang -Tieling Formation section in Beizhangzi, Kuancheng, Northern Hebei; (4) Mesoproterozoic section at Guzifang, Chicheng, Northern Hebei (i.e., Xuanlong section); (5) Mesoproterozoic section at Jixian,Tianjin. (a) Mesoproterozoic strata distribution; (b) coastline; (c) locality; (d) section.

Tianjin. Among these studies, Chu et al. [12] were particularly systematic, although they only represented the Mesoneoproterozoic oxygen and carbon isotope compositions in Jixian and the Ming Tombs and their relation to paleoclimate and sea-level fluctuations, biotic alternation, and tectonic events. To better understand paleoceanic geochemistry of the Yanshan Mountains during the Mesoproterozoic (1.6$1.4 \mathrm{Ga}$ ) and regional, or global, Mesoproterozoic stratigraphic correlation, this study examined oxygen and carbon isotopes in the Mesoproterozoic stratigraphy of Yanshan, North China.

\section{Geologic Setting and Samples}

The Yanshan area is tectonically attributed to a Mesoproterozoic aulacogen basin, which extends on an east-west axis and contains thick deposits from the Mesoproterozoic. In ascending order, these deposits are labeled the Mesoproterozoic Changzhougou, Chuanlinggou, Tuanshanzi, Dahongyu, mainly clastic rocks, Gaoyuzhuang, Yangzhuang, Wumishan, Hongshuizhuang, and Tieling Formations. The latter five formations are the stratigraphic interval of focus here and are chiefly carbonates except for the Hongshuizhuang Formation shale.

The samples for carbon and oxygen isotopic analysis ( 110 samples), as well as analysis of trace elements and oxides, were collected from three individual sections, numbered (1), (2), and (3) in Figure 1. Together, these three sections make up one complete stratigraphic succession of the Mesoproterozoic in northern Hebei Province (Figure 2); Figure 2 shows the regional stratigraphic correlation.

Recent studies have advanced understanding of Mesoproterozoic geochronology in the Yanshan area. Wan et al. [14] studied the Ming Tombs in Beijing and obtained an age range of 1.75-1.80 Ga (SHRIMP age) for the bottom of the Changzhougou Formation. Gao et al. [15-17] reported
SHRIMP zircon ages of $1.37 \mathrm{Ga}$ for the Xiamaling Formation and $1.63 \mathrm{Ga}$ for volcanic rocks in the Dahongyu Formation at Jixian, Tianjin [17]. On the basis of these dates, Qiao et al. [18] and Gao et al. [15-17] suggested the following geochronological framework for the Mesoneoproterozoic: the Changcheng system (Changzhougou Formation, Chuanlinggou Formation, Tuanshanzi Formation, and Dahongyu Formation) is $<1.75 \mathrm{Ga}$; the Jixian system (Gaoyuzhuang Formation, Yangzhuang Formation, Wumishan Formation, Hongshuizhuang Formation, and Tieling Formation) is 1.6$1.4 \mathrm{Ga}$; the Xishan system (Xiamaling Formation) is 1.4$1.2 \mathrm{Ga}$ the top unnamed unit is $1.2-1.0 \mathrm{Ga}$.

Lithology in the research area can be subdivided into three types: (1) primarily micrite carbonate, such as micritic limestone and dolomite; (2) grained carbonate such as algae clastics dolomite, sparry oolitic dolomite, calcarenite, and calcirudite; (3) terrigenous rocks and some siliceous rocks (Table 1).

\section{Methods and Analysis Results}

3.1. Methods. A total of 110 hand samples of carbonate were collected from three sections at Beizhangzi, Kuancheng (no. 3), Weizhangzi, Lingyuan (no. 2), and Jianshanzi, Kuancheng (no. 1) (Figure 3). These sections represent a successive stratigraphic column of the Mesoproterozoic in ascending order. The carbonate samples were first washed and cleaned and then powdered into $75 \mathrm{um}$ grain size. The powdered carbonate samples were reacted with phosphoric acid in an on-line carbonate preparation system (SY/T 6039-94) [SY]. [19]). Carbon and oxygen isotope $\left(\delta^{13} \mathrm{C}\right.$ and $\delta^{18} \mathrm{O}$, resp.) ratios of bulk rocks were analyzed at the Institute of Geology and Mineral Resources (Tianjin, China) using a mass spectrometer (MF-ISOPRIME). All values are reported as per mil (\%o) relative to Vienna Pee Dee Belemnite (V-PDB) in a standard of GBW04405, GBW04406, and 


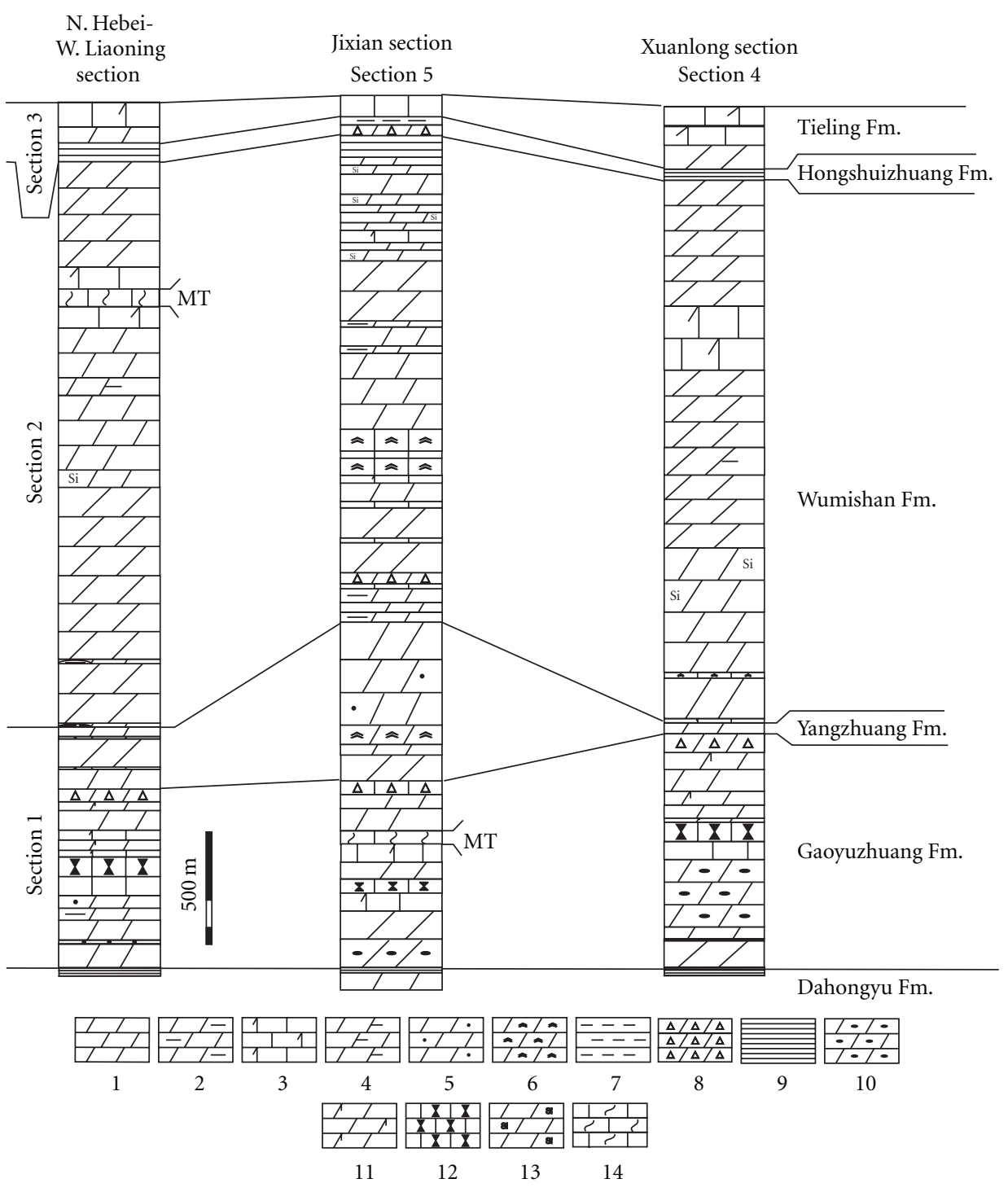

FIGURE 2: Mesoproterozoic stratigraphic columns and regional correlation in Yanshan, North China. (1) Dolostone; (2) muddy dolostone; (3) dolomitic limestone; (4) mud bearing dolostone; (5) sandy dolostone; (6) stromatolitic dolostone; (7) mudstone; (8) breccio-dolostone; (9) shale; (10) chert dolostone; (11) calcite dolostone; (12) nodular limestone; (13) siliceous dolostone; (14) MT limestone; MT-Molar-tooth structure.

TB2GB04417. The precision and accuracy of the isotopic analyses are $\sigma<0.1 \%$, respectively. Concentrations of $\mathrm{Mg}$, $\mathrm{Sr}, \mathrm{Mn}, \mathrm{Fe}$, and $\mathrm{Ca}$ in bulk rocks were also analyzed by inductively coupled plasma mass spectrometry (ICP-MS) at the same institute in Tianjin.

\subsection{Analysis Results}

3.2.1. Diagenesis. Because of the possible complex postdepositional history of carbonates in the study area, we expected that all samples would show geochemical evidence and nonalteration; however, many carbon isotopic studies of Paleozoic and Proterozoic carbonates have shown that carbon isotopic composition is less sensitive to diagenetic alteration than are $\delta^{18} \mathrm{O}$ or trace element ( $\mathrm{Fe}, \mathrm{Mn}, \mathrm{Sr}$ ) compositions, as long as diagenetic fluids are relatively carbon-poor. Tests of diagenesis in Mesoproterozoic carbonates are expected to identify the most chemically altered samples as those that are least likely to preserve meaningful carbon isotopic signatures.

Identification of diagenetic alteration was based on the following: the $\delta^{18} \mathrm{O}-\mathrm{Mg} / \mathrm{Ca}$ ratio, $\delta^{18} \mathrm{O}-\mathrm{Sr}, \delta^{18} \mathrm{O}-\mathrm{Mn}, \delta^{18} \mathrm{O}-$ $\mathrm{Fe}$, and $\mathrm{Fe}-\mathrm{Mn}$ (Figure 3 ). Ratios of $\mathrm{Mg} / \mathrm{Ca}$ cover a range of 0.1 to 0.7 , mainly 0.6 . The $\mathrm{Mg} / \mathrm{Ca}$ ratio is $>0.5$ in dolomite and $0.1-0.5$ in limestone. $\delta^{18} \mathrm{O}$ is a very sensitive indicator of diagenetic processes. Mineralogical examinations of $\delta^{18} \mathrm{O}$ values show that dolostone is isotopically heavy and limestones have low $\delta^{18} \mathrm{O}$.

Previous results indicated that $\delta^{18} \mathrm{O}$ values in Precambrian carbonates generally ranged from approximately -6 to $-9 \%$ except in samples formed in evaporated marine environments $[20,21]$. The current $\delta^{18} \mathrm{O}$ results reveal a higher trend in dolomite than in limestone. Because of evaporation 
TABLE 1: Brief lithologies of Mesoproterozoic strata in the research area.

\begin{tabular}{|c|c|c|c|}
\hline Sections & \multicolumn{2}{|c|}{ Formation and lithological association } & Thickness/m \\
\hline \multirow[t]{2}{*}{ Section 3} & Tieling Formation & $\begin{array}{l}\text { Lower part is grey purple, micritic dolostone, rudite } \\
\text { dolostone bearing } \mathrm{Mn} \text {, and thin bedded calcirudite } \\
\text { with dolomitic limestone rhythm in the middle-upper, } \\
\text { stromatolite calcareous dolostone in the top }\end{array}$ & 211.11 \\
\hline & Hongshuizhuang Formation & $\begin{array}{l}\text { Dark grey shale and argillaceous dolomite in the lower, } \\
\text { muddy dolostone interbedded with silty and sand } \\
\text { dolomite in the upper part. }\end{array}$ & 101.66 \\
\hline Section 2 & Wumishan Formation & $\begin{array}{l}\text { Dolomicrite with stromatolites and ribbon silica, } \\
\text { rhythmic oolitic dolostone, and oncolitic dolostone, } \\
\text { and dolomitic limestone in the upper part }\end{array}$ & 2947.15 \\
\hline \multirow[b]{2}{*}{ Section 1} & Yangzhuang Formation & $\begin{array}{l}\text { Dolomicrite and dolostone with terrigenous clastics } \\
\text { and dolostone with robbon chert }\end{array}$ & 322.37 \\
\hline & Gaoyuzhuang Formation & $\begin{array}{l}\text { Stromatolite dolostone in the lower part, dolomicrite } \\
\text { with Mn, nodular limestone in the middle part and } \\
\text { thick bedded calcareous dolomite or dolomicrite with } \\
\text { ricontaining ribbon chert and breccia dolostone in the } \\
\text { upper part }\end{array}$ & 938.62 \\
\hline
\end{tabular}

and salinization, peritidal (intertidal-supratidal) carbonates have higher values than coeval subtidal carbonates; the former have values of $-2 \%$ in dolomite, and the latter have values of $-8 \%$ in limestone and dolomitic limestone or dolomite.

Trace element content also provides a powerful tool for assessing the degree of diagenesis. The trace elements $\mathrm{Sr}, \mathrm{Mn}$, and Fe exhibit predictable behavior during diagenetic alterations. In general, the $\mathrm{Sr}$ content decreases through interaction with relatively Sr-poor fluids. However, examination of the $\mathrm{Sr}$ content in more than 50 carbonates samples showed low Sr content, mainly 5-50 ppm (Table 2), suggesting poor postdiagenetic alteration.

Contents of $\mathrm{Mn}$ and Fe typically increase with waterrock interaction in the presence of reduced fluids and therefore generally reflect either carbonate precipitation in the presence of $\mathrm{Mn}$ and Fe-rich waters, or postdepositional alteration under burial conditions. Relationships of $\delta^{18} \mathrm{O}$ $\mathrm{Mn}, \delta^{18} \mathrm{O}-\mathrm{Fe}$, and $\mathrm{Fe}-\mathrm{Mn}$ reveal that $\mathrm{Fe}$ and $\mathrm{Mn}$ present distinct and similar trends for limestone and dolostone in the Mesoproterozoic (Table 2 and Figure 3). In most of the samples, $\mathrm{Mn}$ is $<600 \mathrm{ppm}$ and $\mathrm{Fe}$ is <8000 ppm. Relationship of $\delta^{13} \mathrm{C}-\mathrm{Fe}$ and $\delta^{13} \mathrm{C}-\delta^{18} \mathrm{O}$ also suggests that the carbonate samples underwent poor postdepositional diagenetic alterations and well-preserved information on synsedimentary marine oxygen and carbon isotopes in the Mesoproterozoic.

3.2.2. Chemostratigraphy. Table 2 lists the isotopic and elemental compositions, and Figure 4 shows secular change of $\delta^{13} \mathrm{C}$ and $\delta^{18} \mathrm{O}$. The $\delta^{13} \mathrm{C}$ record of the Mesoproterozoic obtained in the current study shows an overall trend of low negative mainly within the Gaoyuzhuang and Yangzhuang Formations. Subsequently, $\delta^{13} \mathrm{C}$ displays low positive variations and stable increase, although with occasional negative values, in the Wumishan Formation; this is followed by a decrease to a negative level of approximately $-1.7 \%$ in the Hongshuizhuang Formation. A rapid increase of $\delta^{13} \mathrm{C}$ occurs from the bottom of the Tieling Formation to the top of the Mesoproterozoic, with $\delta^{13} \mathrm{C}$ values varying between approximately -1.6 and $1 \%$. Oxygen isotope values $\left(\delta^{18} \mathrm{O}\right)$ from this study (Table 2 and Figure 4) show a distinctly negative trend varying from -2.1 to $-10 \%$, excluding diagenetically altered values lower than $-10 \%$. A few highly negative oxygen isotopic shifts occur within the middle Gaoyuzhuang and Yangzhuang Formations and the middle and upper Wumishan Formation. These $\delta^{13} \mathrm{C}$ and $\delta^{18} \mathrm{O}$ results are comparable to previous reports of Mesoproterozoic geochemistry $[4,8,12]$ in Jixian, Tianjin.

\section{Discussion}

The carbon and oxygen isotopic compositions display regular variations that correspond to the evolutionary sedimentary environments in a tidal setting from the Gaoyuzhuang to Yangzhuang Formations. The $\delta^{13} \mathrm{C}$ values vary from approximately 0 to $1.5 \%$. Micritic and stromatolitic dolomite in the Gaoyuzhuang Formation yields a $\delta^{13} \mathrm{C}$ value of approximately $-0.5 \%$. The relatively low $\delta^{13} \mathrm{C}$ value of nodular limestone $(-0.5 \sim 1.5 \%$ o $)$ is consistent with a deep water environment and low biological productivity [22, 23]. Although showing good continuity with $\delta^{13} \mathrm{C}$ values of the Gaoyuzhuang Formation, the Yangzhuang Formation reveals a level of slightly negative $\delta^{13} \mathrm{C}$ values, with a minimum of $-1.35 \%$ in the middle of the formation, possibly due to postdiagenetic alternation, dolomitization, silicification, or terrigenous sediments input. For the Gaoyuzhuang and Yangzhuang Formations, excluding diagenetically altered samples $\left(<-10 \%\right.$ ),$\delta^{18} \mathrm{O}$ shows highly negative values, mostly ranging from approximately -4 to $-7 \%$ with a minimum of $-9.89 \%$. The Wumishan Formation is interpreted as peritidal deposits in an epicontinental sea [6] and 

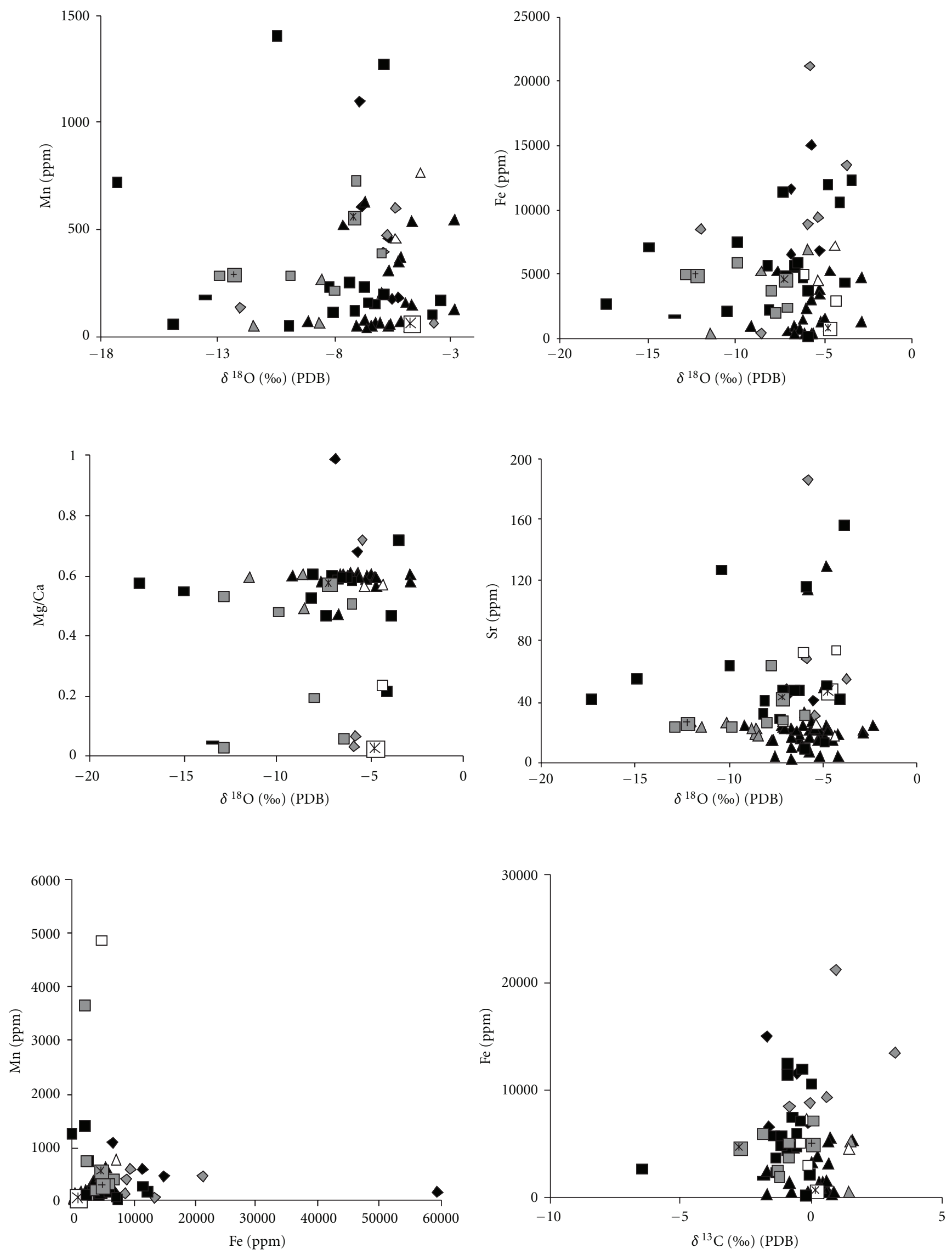

FIgURE 3: Continued. 


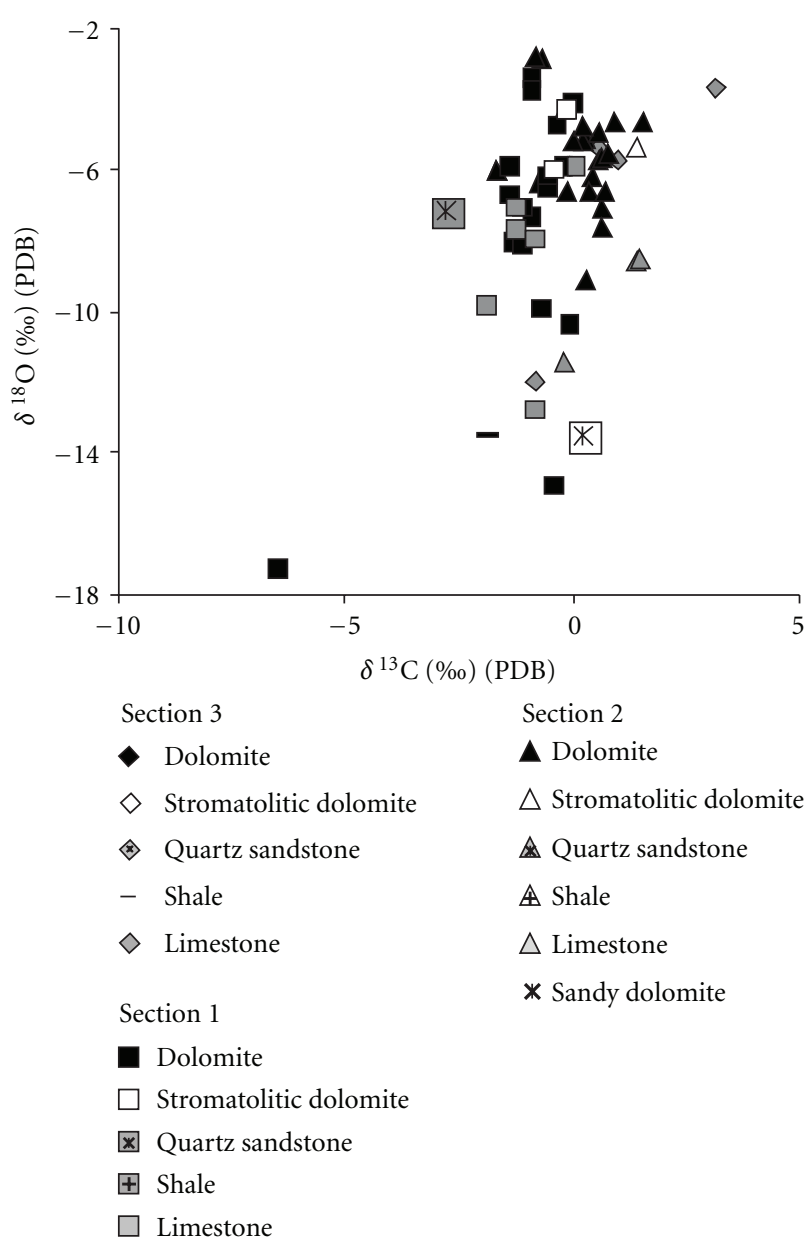

Figure 3: Scatter-plots of Mn, Fe, Mg/Ca, Sr versus $\delta^{18} \mathrm{O}$, Mn versus Fe, Fe versus $\delta^{13} \mathrm{C}$, and $\delta^{13} \mathrm{C}$ versus $\delta^{18} \mathrm{O}$ for the Mesoproterozoic carbonate samples.

characterized by dolomite with stromatolitic laminations. A majority of stromatolites in the Wumishan Formation suggest high biological productivity. The $\delta^{18} \mathrm{O}$ value in this formation varies between $-8.8 \%$ and $-2.3 \%$, displaying a slight decrease upwards. Except for two positive drifts of $\delta^{13} \mathrm{C}$, reaching 1.56 at the bottom and 1.49 at the top, the other values vary around zero, probably induced by high-frequency sea-level changes, palaeotemperature, or productivity. The Hongshuizhuang Formation is composed of dark-gray shale rich in organic material with dolomitic intercalations and a lower negative $\delta^{13} \mathrm{C}$ value $(-1.7 \%$ ) and a moderate $\delta^{18} \mathrm{O}$ value $(-5.5 \%)$. The Tieling Formation shows a lower negative trend of $\delta^{13} \mathrm{C}$ varying between $-1.7 \%$ and $1.18 \%$ in the lower part, with an increase of positive values $(-0.6 \sim 1 \% 0)$ upwards. The $\delta^{18} \mathrm{O}$ of this unit maintains a stable level of $-6.9 \sim 5.3 \%$, possibly reflecting a response to the sedimentary environmental transition from supratidal to intertidal-subtidal and an increase of biological activity.

Previous studies on carbon isotopes of the Mesoproterozoic $[7,8,11,12]$ showed that $\delta^{13} \mathrm{C}$ values during $1.8-1.6 \mathrm{Ga}$ were mainly negative ( -3 to $0 \%$ ) and increased slowly, reaching a level of zero, with abrupt oscillation occurring at the beginning of $1.6 \mathrm{Ga}$. Zhai and Piao [24] and Chu et al. [12] concluded that the evolutionary trend of carbon isotopes was a geochemical record that corresponded to break up of the supercontinent in the Early Mesoproterozoic. Li et al. [11] suggested, based upon geochemistry, that high salt concentration of the paleocean spurred the evolution of the microorganism community, which resulted in the variation of $\delta^{13} \mathrm{C}$ isotopes in sediments during this period.

Knauth and Lowe [25], De La Rocha [26], and Robert and Chaussidon [27] suggested that during the interval of 1.4-1.2 Ga, ocean temperature reached around $70^{\circ} \mathrm{C}$ based on study of global average $\delta^{18} \mathrm{O}$ and $\delta^{30} \mathrm{Si}$ isotopes in carbonates. The $\delta^{13} \mathrm{C}$ values of Mid-Riphean carbonate from the southern Urals of Russia $(1.4-1.2 \mathrm{Ga})$ show a low positive range of $0-3 \%$ and a negative anomaly below $-20 \%$ o (Bartley et al., [28]) in black shale. The $\delta^{13} \mathrm{C}$ in the Mesoproterozoic Belt Supergroup (1.45-1.20 Ga) in North America and Canada, consisting mainly of carbonate-bearing molar-tooth structure, varies from -0.2 to $1.4 \%$ from down to up [20], while $\delta^{13} \mathrm{C}$ in carbonates of $1.70-1.60 \mathrm{Ga}$ in the McArthur and Mount Isa basins in northern Australia displays stable variation of -0.6 to $1 \%$ [29]. A carbon isotope curve for ca. 1.6-0.6 Ga reported 


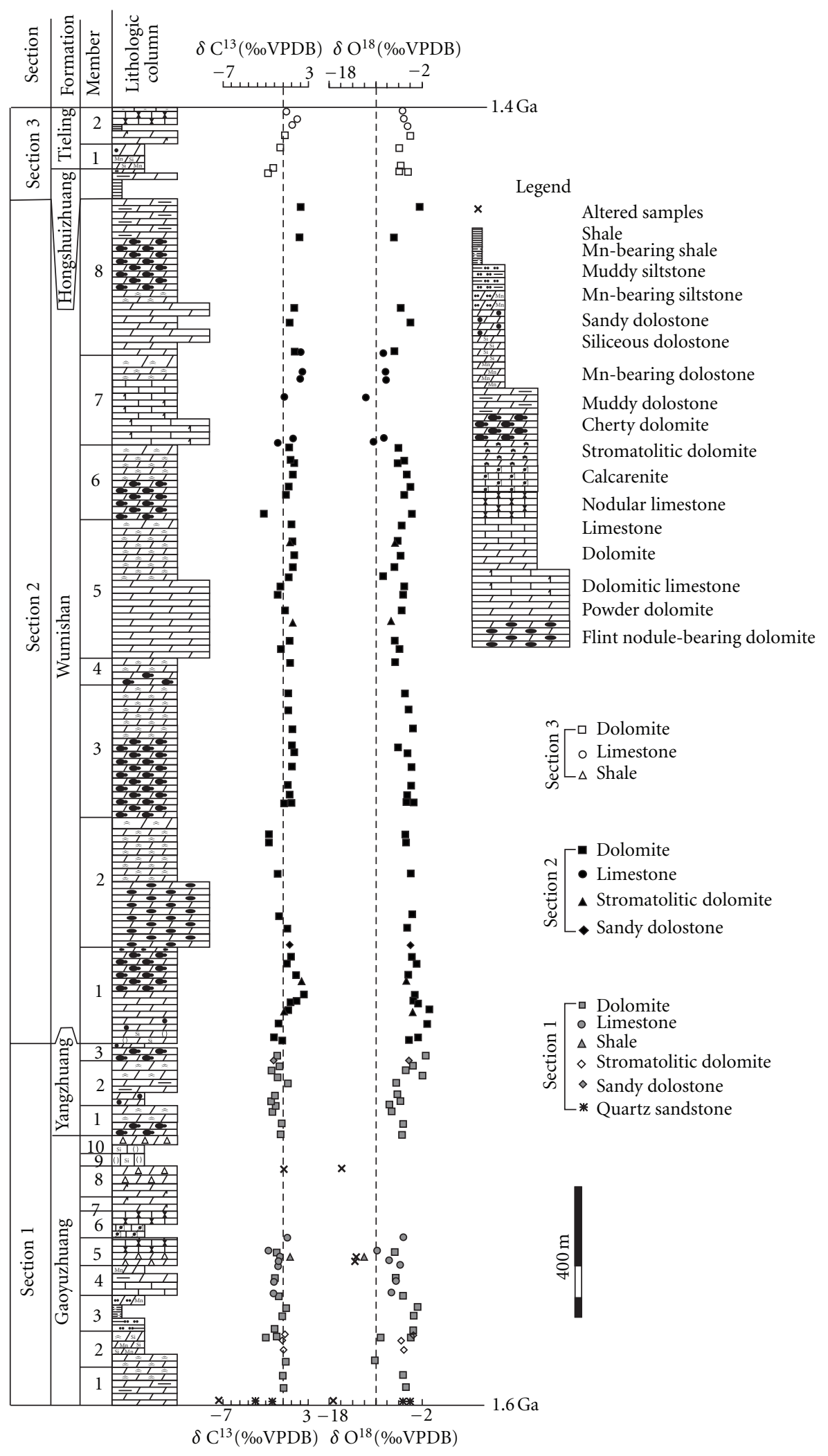

FIGURE 4: Stratigraphic variation in carbon and oxygen isotopic compositions of Mesoproterozoic carbonates from Yanshan, North China. 
TABLE 2: Isotopic and elemental compositions of Mesoproterozoic carbonates from Yanshan, North China.

\begin{tabular}{|c|c|c|c|c|c|c|c|c|}
\hline Formation & Samples & Stratigraphic depth/m & Lithologies & $\delta^{13} \mathrm{C} / \%$ (PDB) & $\delta^{18} \mathrm{O} / \% 0(\mathrm{PDB})$ & $\mathrm{Mn} / \mathrm{Sr}$ & $\mathrm{Sr} / \mathrm{ppm}$ & $\overline{\mathrm{Mg} / \mathrm{Ca}}$ \\
\hline \multirow[t]{9}{*}{ Tieling Fm. } & Ktl-46-T1 & 536.03 & Micritic limestone & 0.0 & -5.9 & 3.18 & 63.3 & 0.03 \\
\hline & Ktl-40-T1 & 563.33 & Limestone & 1.0 & -5.8 & 3.15 & 59.0 & 0.07 \\
\hline & Ktl-36-T1 & 581.47 & Argillaceous limestone & 0.6 & -5.4 & 5.37 & 56.3 & 0.72 \\
\hline & Ktl-29-T2 & 606.44 & Micritic dolostone & -0.2 & -5.2 & & & \\
\hline & Ktl-29-T1 & 607.44 & Argillaceous dolostone & -0.1 & -5.3 & & & 1.89 \\
\hline & Ktl-28-T1 & 650.17 & Micritic dolostone & -0.6 & -6.8 & 271.28 & 43.5 & 2.17 \\
\hline & Ktd-16-T1 & 720.81 & Breccia dolostone & -1.2 & -6.8 & & & \\
\hline & Ktd-12-T2 & 737.24 & Micritic dolostone & -1.7 & -5.7 & & & 0.68 \\
\hline & Ktd-12-T1 & 737.34 & Micritic dolostone & -1.6 & -6.9 & 29.4 & 44.3 & 0.99 \\
\hline \multicolumn{2}{|c|}{ Hongshuizhuang Fm. KH-11-T1 } & 738.04 & Micritic dolostone & -1.7 & -5.5 & 84.01 & 40.6 & 2.01 \\
\hline \multirow{40}{*}{ Wumishan Fm. } & LW-409-T1 & 857.77 & Micritic dolostone & 1.3 & -4.0 & & & \\
\hline & LW-395-T1 & 963.96 & Micritic dolostone & 1.1 & -7.7 & & & \\
\hline & LW-356-T1 & 1213.39 & dolostone bearing MT & 0.7 & -6.6 & & & \\
\hline & LW-347-T1 & 1265.3 & Micritic dolostone & 0.3 & -5.2 & 6.11 & 10.2 & 0.6 \\
\hline & LW-331-T1 & 1364.92 & Calcareous dolostone & 0.8 & -7.8 & & & \\
\hline & LW-329-T1 & 1375.58 & Dolomitic limestone & 1.5 & -8.6 & 0.49 & 94.9 & 0.61 \\
\hline & LW-324-T1 & 1446.5 & Micritic limestone & 1.5 & -8.6 & 1.17 & 86.1 & 0.49 \\
\hline & LW-321-T1 & 1467.67 & MT limestone in situ & 1.3 & -8.4 & & & \\
\hline & LW-315-T1 & 1531.43 & Micritic limestone & -0.2 & -11.5 & 0.54 & 115.0 & 0.6 \\
\hline & LW-299-T1 & 1676.2 & MT micriticlimestone & 0.6 & -8.8 & & & \\
\hline & LW-295-T1 & 1694.04 & Dolomitic limestone & -0.8 & -10.2 & & & \\
\hline & LW-293-T1 & 1702.94 & Micritic dolostone & 0.2 & -7.1 & & & \\
\hline & LW-287-T1 & 1745.94 & Powder dolostone & 0.5 & -6.2 & 2.72 & 34.2 & 0.6 \\
\hline & LW-286-T1 & 1752.03 & Powder dolostone & 0.7 & -7.1 & 2.26 & 27.5 & 0.57 \\
\hline & LW-278-T1 & 1795.39 & Powder dolostone & 0.6 & -5.7 & 2.97 & 20.9 & 0.61 \\
\hline & LW-270-T1 & 1840.77 & Dolostone & 0.2 & -5.2 & 6.73 & 31.1 & 0.59 \\
\hline & LW-265-T1 & 1866.38 & Algal dolostone & 0.0 & -6.1 & & & \\
\hline & LW-257-T1 & 1930.82 & Dolostone & -2.1 & -5.2 & & & \\
\hline & LW-249-T1 & 1973.53 & Algal dolostone & 0.4 & -6.7 & 2.49 & 18.7 & 0.59 \\
\hline & LW-240-T1 & 2027.2 & Sparry dolostone & 0.5 & -7.2 & & & \\
\hline & LW-238-T1 & 2046.83 & Stromatolite dolostone & 0.4 & -7.1 & & & \\
\hline & LW-233-T1 & 2079.2 & Powder dolostone & 0.7 & -6.7 & 17.92 & 19.5 & 0.48 \\
\hline & LW-227-T1 & 2117.68 & Powder dolostone & 0.7 & -7.7 & 17.38 & 20.1 & 0.58 \\
\hline & LW-223-T1 & 2150.28 & Algal dolostone & 0.3 & -9.2 & 15.04 & 26.3 & 0.6 \\
\hline & LW-218-T1 & 2184.96 & Powder dolostone & -0.5 & -6.3 & & & \\
\hline & LW-213-T1 & 2217.08 & Dolostone & -0.8 & -6.4 & 17.2 & 18.0 & 0.61 \\
\hline & LW-207-T1 & 2271.37 & Powder dolostone & -0.1 & -6.6 & 7.83 & 19.8 & 0.6 \\
\hline & LW-201-T1 & 2321.32 & Stromatolite olostone & 0.6 & -7.8 & & & \\
\hline & LW-196-T1 & 2375.19 & Dolostone & 0.3 & -7.6 & & & \\
\hline & LW-192-T1 & 2405.43 & Powder dolostone & -0.5 & -7.0 & & & \\
\hline & LW-184-T1 & 2451.98 & Dolostone & 0.4 & -7.6 & & & \\
\hline & LW-175-T1 & 2559.8 & Powder dolostone & 0.2 & -6.1 & & & \\
\hline & LW-167-T1 & 2617.95 & Algal dolostone & 0.1 & -5.5 & & & \\
\hline & LW-162-T1 & 2684.71 & Siliceous dolostone & 0.6 & -5.0 & 1.68 & 23.1 & 0.61 \\
\hline & LW-158-T1 & 2749.17 & Powder dolostone & 0.5 & -7.0 & & & \\
\hline & LW-155-T1 & 2767.03 & Powder dolostone & 0.6 & -5.7 & 1.48 & 31.4 & 0.6 \\
\hline & LW-148-T1 & 2819.09 & Powder dolostone & 0.6 & -5.2 & & & \\
\hline & LW-138-T1 & 2882.64 & Dolostone & 0.0 & -5.2 & 59.03 & 8.8 & 0.59 \\
\hline & LW-132-T1 & 2915.65 & Dolostone & 0.3 & -5.7 & & & \\
\hline & LW-128-T2 & 2941.69 & Powder dolostone & 0.0 & -5.8 & & & \\
\hline
\end{tabular}


Table 2: Continued.

\begin{tabular}{|c|c|c|c|c|c|c|c|c|}
\hline Formation & Samples & Stratigraphic depth/m & Lithologies & $\delta^{13} \mathrm{C} / \%$ (PDB) & $\delta^{18} \mathrm{O} / \%$ (PDB) & $\mathrm{Mn} / \mathrm{Sr}$ & Sr/ppm & $\mathrm{Mg} / \mathrm{Ca}$ \\
\hline & LW-128-T1 & 2943.79 & Dolostone & 0.3 & -4.8 & 2.98 & 15.6 & 0.6 \\
\hline & LW-119-T1 & 3054.87 & Siliceous dolostone & -1.7 & -6.1 & 2.16 & 25.1 & 0.61 \\
\hline & LW-113-T1 & 3079.65 & Siliceous dolostone & -1.7 & -6.0 & 16.96 & 21.9 & 0.6 \\
\hline & LW-99-T1 & 3192.1 & Dolostone & -0.8 & -5.2 & & & \\
\hline & LW-73-T1 & 3334.6 & Powder dolostone & -0.7 & -4.8 & & & \\
\hline & LW-67-T1 & 3381.68 & Powder dolostone & 0.0 & -5.8 & & & \\
\hline & LW-57-T1 & 3448.42 & Powder dolostone & 0.2 & -4.7 & 2.09 & 22.3 & 0.03 \\
\hline & LW-52-T1 & 3483.76 & Dolostone & 0.4 & -4.9 & & & \\
\hline & LW-50-T1 & 3504.88 & Dolostone & 0.0 & -4.4 & & & \\
\hline & LW-44-T1 & 3543.89 & Dolostone & 0.8 & -5.6 & 4.07 & 15.2 & 0.6 \\
\hline & LW-39-T1 & 3578.55 & Stromatolite dolostone & 1.4 & -5.4 & 3.31 & 25.7 & 0.57 \\
\hline & LW-33-T1 & 3618.71 & Powder dolostone & 1.6 & -4.7 & 2.13 & 25.4 & 0.57 \\
\hline & LW-30-T1 & 3636.91 & Dolostone & 0.9 & -4.7 & 2.45 & 25.3 & 0.6 \\
\hline & LW-29-T1 & 3641.91 & Dolostone & 0.5 & -4.2 & & & \\
\hline & LW-24-T1 & 3665.83 & Dolostone & 0.2 & -2.3 & & & \\
\hline & LW-22-T1 & 3687.32 & Algal dolostone & -0.2 & -4.3 & 1.62 & 33.5 & 0.57 \\
\hline & LW-20-T1 & 3715.37 & Dolostone & -0.7 & -2.9 & 3 & 18.1 & 0.6 \\
\hline & LW-13-T1 & 3762.27 & Dolostone & -1.1 & -4.2 & & & \\
\hline & LW-11-T1 & 3776.1 & Dolostone & -0.3 & -5.5 & & & \\
\hline & LW-3-T1 & 3826.82 & Muddy dolostone & -0.8 & -2.8 & 3.44 & 31.5 & 0.58 \\
\hline \multirow[t]{12}{*}{ Yangzhuang Fm. } & KY2-217-T1 & 3849.48 & Sandy dolostone & -1.3 & -5.1 & & & \\
\hline & KY2-216-T1 & 3849.98 & Muddy dolostone & -0.9 & -3.8 & 1.55 & 156.2 & 0.47 \\
\hline & KY2-214-T1 & 3861.28 & Muddy dolostone & -0.7 & -4.9 & & & \\
\hline & KY2-212-T1 & 3876.08 & Muddy dolostone & -1.4 & -5.9 & 14.23 & 9.2 & 0.58 \\
\hline & KY2-207-T1 & 3897.09 & Muddy dolostone & -0.9 & -3.5 & & & \\
\hline & KY2-201-T1 & 3921.36 & Siliceous dolostone & 0.1 & -7.3 & & & \\
\hline & KY2-194-T1 & 3965.2 & Siliceous dolostone & -1.1 & -7.1 & 3.63 & 47.7 & 0.6 \\
\hline & KY2-192-T1 & 3983.89 & Siliceous dolostone & -1.4 & -6.7 & & & \\
\hline & KY1-190-T1 & 4006.3 & Siliceous dolostone & -1.1 & -8.2 & 5.76 & 31.4 & 0.52 \\
\hline & KY1-187-T1 & 4016.91 & Siliceous dolostone & -1.3 & -8.1 & 4.09 & 40.3 & 0.6 \\
\hline & KY1-180-T1 & 4064.11 & Siliceous dolostone & -0.5 & -6.2 & 5.98 & 46.9 & 0.59 \\
\hline & KY1-174-T1 & 4100.75 & Siliceous dolostone & -0.6 & -6.5 & 1.72 & 47.2 & 0.59 \\
\hline \multirow[t]{15}{*}{ Gaoyuzhuang Fm. } & Gh1-170-T1 & 4191.12 & Algal dolostone & -0.7 & -9.9 & & & \\
\hline & Gh1-168-T1 & 4217.14 & Calcareous dolostone & -0.4 & -14.9 & 19.2 & 54.7 & 0.55 \\
\hline & Gz2-147-T1 & 4472.34 & Breccia limestone & 0.1 & -5.9 & 3.94 & 31.0 & 0.51 \\
\hline & Gz2-141-T2 & 4519.32 & Dolostone & -0.9 & -7.3 & 4.75 & 28.9 & 0.47 \\
\hline & Gz2-141-T1 & 4519.32 & Nodular limestone & -1.8 & -9.9 & 13.96 & 22.7 & 0.48 \\
\hline & Gz2-137-T1 & 4538.71 & Nodular limestone & -0.7 & -12.9 & & & \\
\hline & Gz2-135-T2 & 4547.75 & Siliceous shale & 0.0 & -12.3 & & & \\
\hline & Gz2-135-T1 & 4548.15 & Limestone lens & -0.8 & -12.9 & 2.46 & 23.2 & 0.53 \\
\hline & Gz2-134-T1 & 4552.65 & Siliceous limestone & -0.8 & -8.0 & 1.63 & 16.1 & 0.19 \\
\hline & Gz1-133-T1 & 4571.12 & Muddy limestone & -0.9 & -6.4 & & & \\
\hline & Gz1-126-T1 & 4608.43 & Calcareous dolostone & -1.1 & -7.4 & & & \\
\hline & Gz1-122-T1 & 4627.76 & Nodular limestone & -1.3 & -7.1 & & & \\
\hline & Gz1-113-T1 & 4664.23 & Dolomitic limestone & -1.2 & -7.7 & & & \\
\hline & Gs-111-T1 & 4675.53 & Dolostone with Mn & -0.7 & -6.2 & & & \\
\hline & Gs-98-T1 & 4714.52 & Dolostone with Mn & 0.0 & -4.1 & 1.31 & 42.3 & 0.22 \\
\hline
\end{tabular}


TABle 2: Continued.

\begin{tabular}{|c|c|c|c|c|c|c|c|c|}
\hline Formation & Samples & Stratigraphic depth/m & Lithologies & $\delta^{13} \mathrm{C} / \%$ (PDB) & $\delta^{18} \mathrm{O} / \%$ (PDB) & $\mathrm{Mn} / \mathrm{Sr}$ & $\mathrm{Sr} / \mathrm{ppm}$ & $\mathrm{Mg} / \mathrm{Ca}$ \\
\hline & Gs-96-T1 & 4744.45 & Dolostone with $\mathrm{Mn}$ & -0.4 & -4.8 & & & \\
\hline & Gg2-91-T1 & 4791.6 & Muddy dolostone & -1.1 & -4.8 & & & \\
\hline & Gg2-89-T1 & 4812.78 & Stromatolite dolostone & -0.1 & -4.3 & 0.97 & 73.6 & 0.23 \\
\hline & Gg2-88-T1 & 4814.78 & Muddy dolostone & -0.9 & -5.1 & & & \\
\hline & Gg2-87-T1 & 4818.92 & Silicite & -1.9 & -9.6 & & & \\
\hline & Gg2-83-T1 & 4834.27 & Stromatolite dolostone & -0.4 & -6.1 & & & \\
\hline & Gg1-72-T1 & 4866.67 & Stromatolite dolostone & -0.2 & -5.7 & & & \\
\hline & Gg1-58-T1 & 4901.87 & Siliceous dolostone & -0.1 & -10.4 & & & \\
\hline & Gg1-47-T1 & 4951.22 & Dolostone & -0.3 & -6.2 & & & \\
\hline & Gg1-35-T1 & 4994.67 & Dolostone & -0.2 & -5.9 & & & \\
\hline & Gg1-29-T1 & 5034.38 & Dolostone & -6.5 & -17.3 & 4.09 & 41.6 & 0.57 \\
\hline & Gg1-28-T2 & 5046.59 & Quartz sandstone & -1.9 & -7.5 & & & \\
\hline & Gg1-28-T1 & 5047.09 & Quartz sandstone & -2.8 & -7.2 & 5.4 & 42.6 & 0.58 \\
\hline
\end{tabular}

by Kah et al. [21] presents a slow increase in $\delta^{13} \mathrm{C}$ values above $0 \%$, comparable to the $\delta^{13} \mathrm{C}$ profiles of the present study and suggesting that a global marine geochemical system prevailed and was universally correlated during the interval of $1.6-1.2 \mathrm{Ga}$, in response to the global tectonic background.

\section{Conclusions}

The bulk-rock carbon and oxygen isotopic compositions and profiles obtained from carbonates from central and northern Yanshan provide a paleogeochemical record of ocean depositional environments, temperature, biological productivity, and sea-level fluctuations. From the early to late Mesoproterozoic, low negative $\delta^{13} \mathrm{C}$ values appear in both the Gaoyuzhuang and Yangzhuang Formations. This is followed by low positive variations and a stable increase with occasional negative value in the Wumishan Formation. An abrupt decrease in $\delta^{13} \mathrm{C}$ values, down to $-1.7 \%$, occurs in the Hongshuizhuang Formation; $\delta^{13} \mathrm{C}$ values then rapidly increase from the bottom of the Tieling Formation to the end of the Mesoproterozoic, varying between $-1.6 \%$ and $1 \%$.

The main $\delta^{18} \mathrm{O}$ trend is negative value, varying from $-2.3 \%$ o to $-10 \%$. A few highly negative oxygen isotopic shifts occur within the middle Gaoyuzhuang Formation, the Yangzhuang Formation, and the middle and upper Wumishan Formation.

The carbon and oxygen isotope profiles of this study correspond well with results of other international studies, suggesting that a global marine geochemical system existed during the past $1.4 \mathrm{Ga}$ interval and revealing a globally united tectonic, sedimentary, and geochemical background.

\section{Acknowledgment}

Financial supports from the National Natural Science Foundation of China (no. 40772078), SINOPIC (no. GB0800-06ZS-350) and Geology Institute of CAGS (no. J0903) are all acknowledged.

\section{References}

[1] J. Chen, H. Zhang, S. Zhu, Z. Zhao, and Z. Wang, "Research on Sinian suberathern of Jixian, Tianjin," in Bureau of Geology and Mineral Resources of Tianjing, Research on Pricambrian Geology, pp. 56-114, Tianjin Science and Technology Press, Tianjin, China, 1980.

[2] Z. Gao, Y. Xiong, and P. Gao, "Preliminary notes on Sinian stratigraphy of North China," Bulletin of Geological Society of China, vol. 13, pp. 243-388, 1934 (Chinese).

[3] T. Wu, "Late Precambrian (Meso-to Neoproterozoic) lithostratigraphic units in North China and their multiple division and correlation," Geology in China, vol. 29, no. 2, pp. 147-154, 2002 (Chinese).

[4] H. Zhong and J. Chen, "Carbon isotope evidence for lower biomass about $1400 \mathrm{Ma}$ ago," Scientia Geologica Sinica, no. 2, pp. 160-168, 1992 (Chinese).

[5] K. Wang and J. Chen, "Constaints on the stable isotopic composition of sedimentary carbonates from the Tieling Formation in the Yanshan region," Geochimica, no. 1, pp. 1017, 1993 (Chinese).

[6] Z. Zhao, "Characteristics of Proterozoic carbonate rocks in Jixian by means of the oxygen and carbon isotope composition," Acta Sedimentologica Sinica, vol. 13, no. 3, pp. 46-53, 1995 (Chinese).

[7] C. Zhao, R. Li, and J. Zhou, Sedimentology and Petroleum Geology of the Meso-and Neo-Proterozoic in North China, Geological Publishing House, Beijing, China, 1997.

[8] S. Xiao, A. H. Knoll, A. J. Kaufman, L. Yin, and Y. Zhang, "Neoproterozoic fossils in Mesoproterozoic rocks? Chemostratigraphic resolution of a biostratigraphic conundrum from the North China Platform," Precambrian Research, vol. 84, no. 3-4, pp. 197-220, 1997.

[9] R. Li, J. Chen, and S. Zhang, "Stable carbon and oxygen isotopic compositions of carbonates in middle Mesoproterozoic Wumishan Formation and sea-level change," Chinese Science Bulletin, vol. 44, no. 23, pp. 2130-2136, 1999 (Chinese).

[10] R. Li, J. Chen, and Z. Chen, "Characteristics of the C-and Oisotopic compositions of carbonates in the weathering profile at the unconformable boundary between the early cambrian and late Proterozoic in Ji County, North China," Chinese Journal of Geology (Scientia Geologica Sinica), vol. 35, no. 1, pp. 55-59, 2000 (Chinese). 
[11] C. Li, P. Peng, G. Sheng, J. Fu, and Y. Yan, "A carbon isotopic biogeochemical study of Meso- to Neoproterozoic sediments from the Jixian section, North China," Acta Geologica Sinica, vol. 76, no. 4, pp. 433-440, 2002 (Chinese).

[12] X. Chu, T. Zhang, Q. Zhang, L. Feng, and F. Zhang, "Carbon istopic variations of Proterozoic carbonates in Jixian, Tianjin, China," Science in China Series D, vol. 47, no. 2, pp. 160-170, 2004.

[13] S. Zhu, X. Huang, and S. Sun, "New progress in the research of the Mesoproterozoic Changcheng system (1800-1400) in the Yanshan range, North China," Journal of Stratigraphy, vol. 29, no. B11, pp. 437-449, 2005 (Chinese).

[14] Y. Wan, Q. Zhang, and T. Song, "SHRIMP ages of detrital zircons from the Changcheng System in the Ming Tombs area, Beijing: constraints on the protolith nature and maximum depositional age of the Mesoproterozoic cover of the North China Craton," Chinese Science Bulletin, vol. 48, no. 22, pp. 1970-1975, 2003 (Chinese).

[15] L. Gao, C. Zhang, X. Shi, H. Zhou, and Z. Wang, "A new SHRIMP age of the Xiamaling formation in the North China plate and its geological significance," Acta Geologica Sinica, vol. 81, no. 6, pp. 1103-1109, 2007.

[16] L. Gao, C. Zhang, X. Shi, H. Zhou, and Z. Wang, "Zircon SHRIMP $\mathrm{U}-\mathrm{Pb}$ dating of the tuff bed in the Xiamaling formation of the Qingbaikouan System in North China," Geological Bulletin of China, vol. 26, no. 3, pp. 249-255, 2007.

[17] L. Gao, C. Zhang, C. Yin et al., "SHRIMP Zircon ages: basis for refining the chronostratigraphic classification of the Mesoand Neoproterozoic Strata in North China Old Land," Acta Geoscientica Sinica, vol. 29, no. 3, pp. 366-376, 2008.

[18] X. Qiao, L. Gao, and C. Zhang, "New idea of the Mesoand Neoproterozoic chronostratigraphic chart and tectonic environment in Sino-Korean Plate," Geological Bulletin of China, vol. 26, no. 5, pp. 503-509, 2007.

[19] China National Petroleum Corporation (CNPC), "The standard method of phosphorolysis for carbon and oxygen isotopes determination of carbonate rocks (SY/T 6039-94) [SY]," 1995.

[20] T. D. Frank, T. W. Lyons, and K. C. Lohmann, "Isotopic evidence for the paleoenvironmental evolution of the mesoproterozoic Helena formation, belt supergroup, Montana, USA," Geochimica et Cosmochimica Acta, vol. 61, no. 23, pp. 5023-5041, 1997.

[21] L. C. Kah, T. W. Lyons, and J. T. Chesley, "Geochemistry of a 1.2 Ga carbonate-evaporite succession, northern Baffin and Bylot Islands: implications for Mesoproterozoic marine evolution," Precambrian Research, vol. 111, pp. 203-234, 2001.

[22] Z. Yan, F. Guo, J. Pan, G. Guo, and R. Zhang, "Application of C, $\mathrm{O}$ and $\mathrm{Sr}$ isotope composition of carbonates in the research of paleoclimate and paleooceanic environment," Contributions to Geology and Mineral Resources Research, vol. 20, no. 1, pp. 5356, 2005.

[23] C. Guo, Z. Wang, and F. Wang, "Stable isotopic characteristics of diagenesisin deep water carbonate rocks," Oil \& Gas Geology, vol. 20, no. 2, pp. 48-51, 1999.

[24] M. Zhai and A. Piao, "The amalgamation of the supercontinent of North China Craton at the end of Neo-Archaean and its breakup during late Paleoproterozoic an MesoProterozoic," Science in China, Series D, vol. 43, supplement 1, pp. 129-137, 2000 (Chinese).
[25] L. P. Knauth and D. R. Lowe, "High Archean climatic temperature inferred from oxygen isotope geochemistry of cherts in the 3.5 Ga Swaziland Supergroup, South Africa," Bulletin of the Geological Society of America, vol. 115, no. 5, pp. 566-580, 2003.

[26] C. L. De La Rocha, "Palaeoceanography: in hot water," Nature, vol. 443, no. 7114, pp. 920-921, 2006.

[27] F. Robert and M. Chaussidon, "A palaeotemperature curve for the Precambrian oceans based on silicon isotopes in cherts," Nature, vol. 443, no. 7114, pp. 969-972, 2006.

[28] J. K. Bartley, L. C. Kah, J. L. McWilliams, and A. F. Stagner, "Carbon isotope chemostratigraphy of the Middle Riphean type section (Avzyan Formation, Southern Urals, Russia): Signal recovery in a fold-and-thrust belt," Chemical Geology, vol. 237, no. 1-2, pp. 211-232, 2007.

[29] J. F. Lindsay and M. D. Brasier, "A carbon isotope reference curve for ca. 1700-1575 Ma, McArthur and Mount Isa Basins, Northern Australia," Precambrian Research, vol. 99, no. 3-4, pp. 271-308, 2000. 

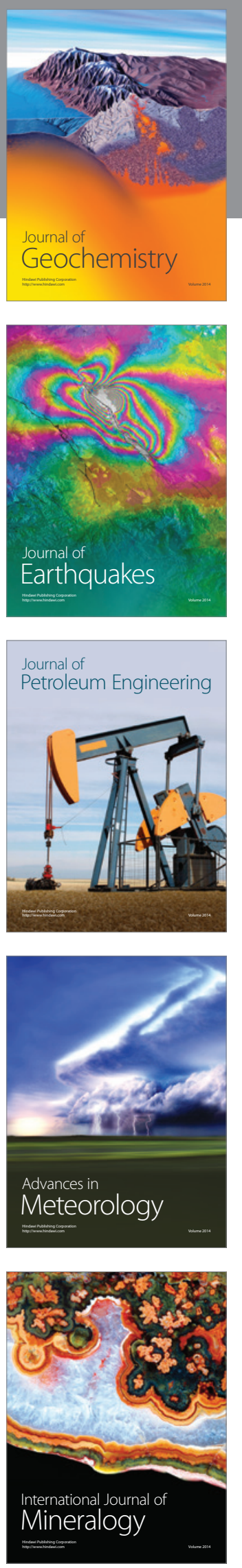
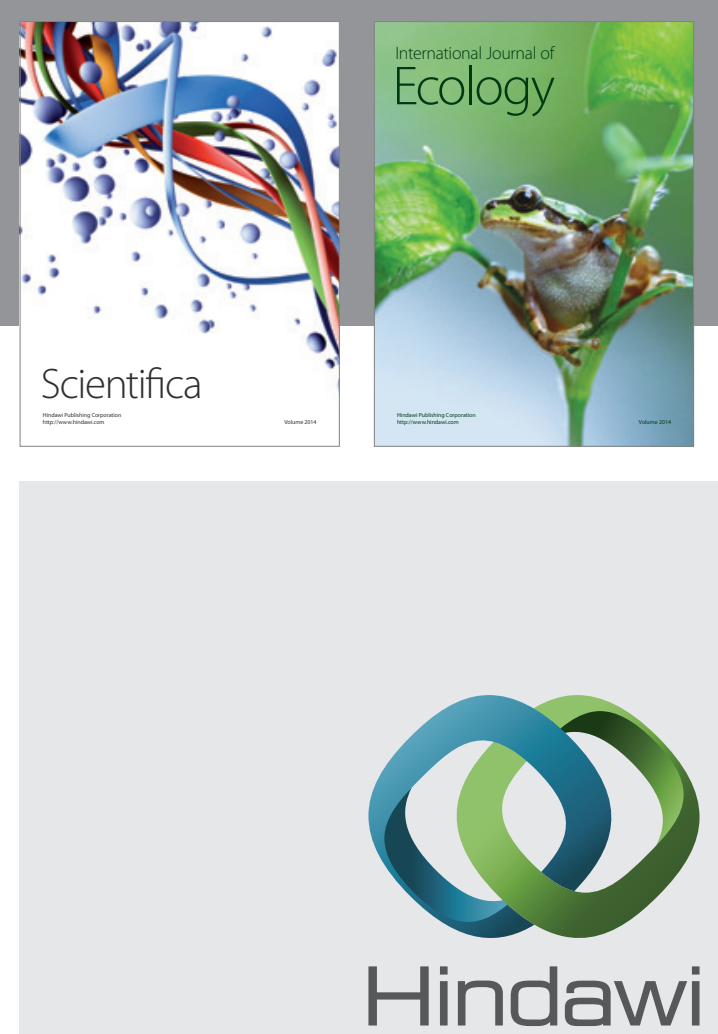

Submit your manuscripts at http://www.hindawi.com
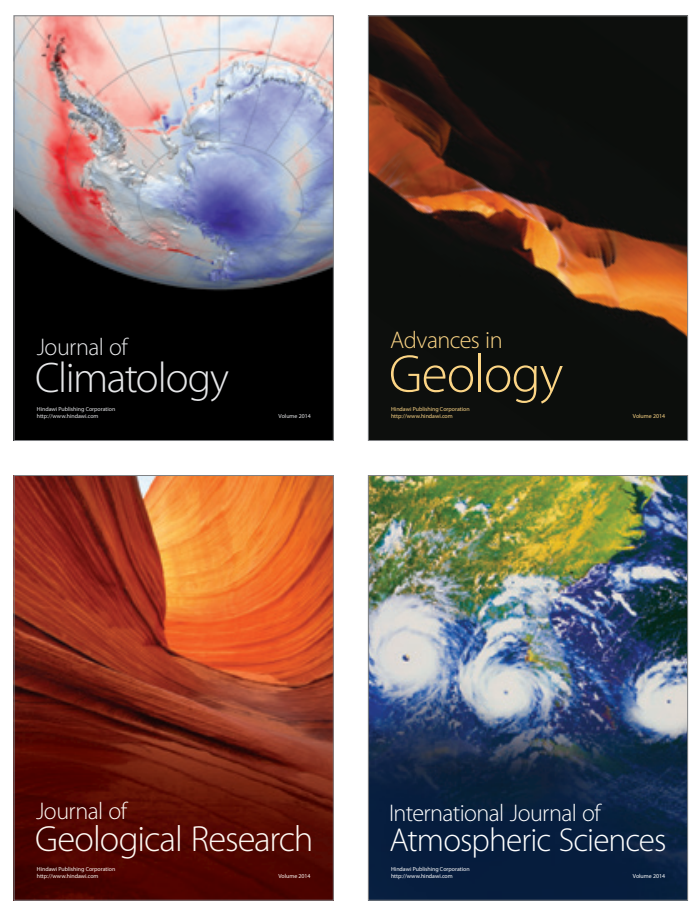
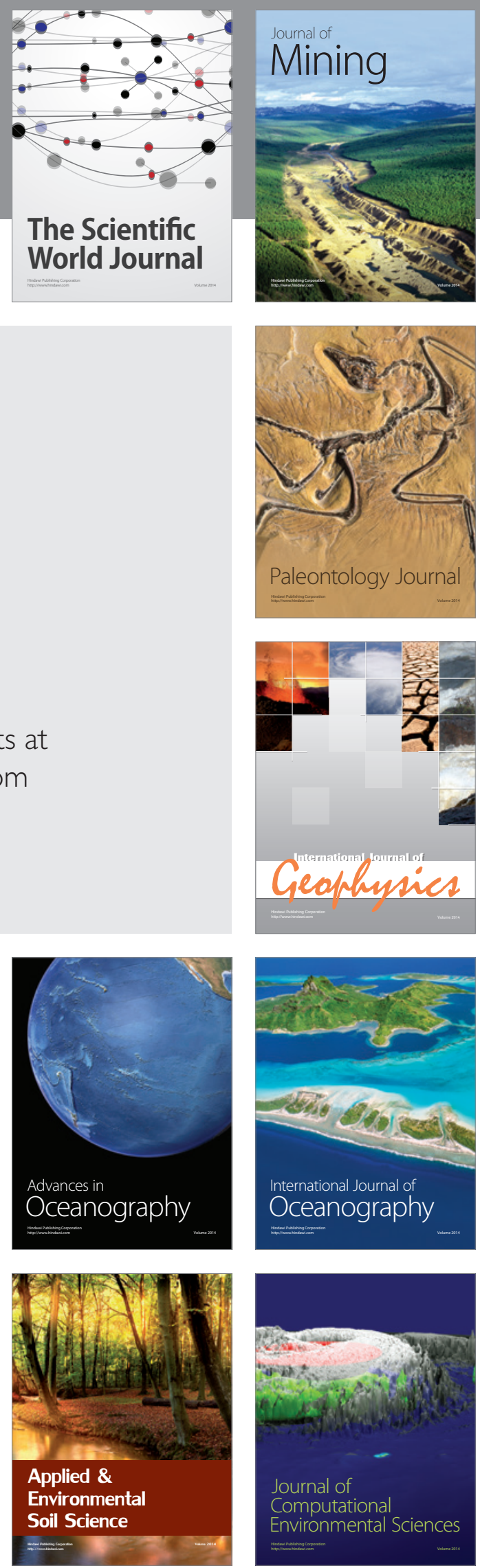